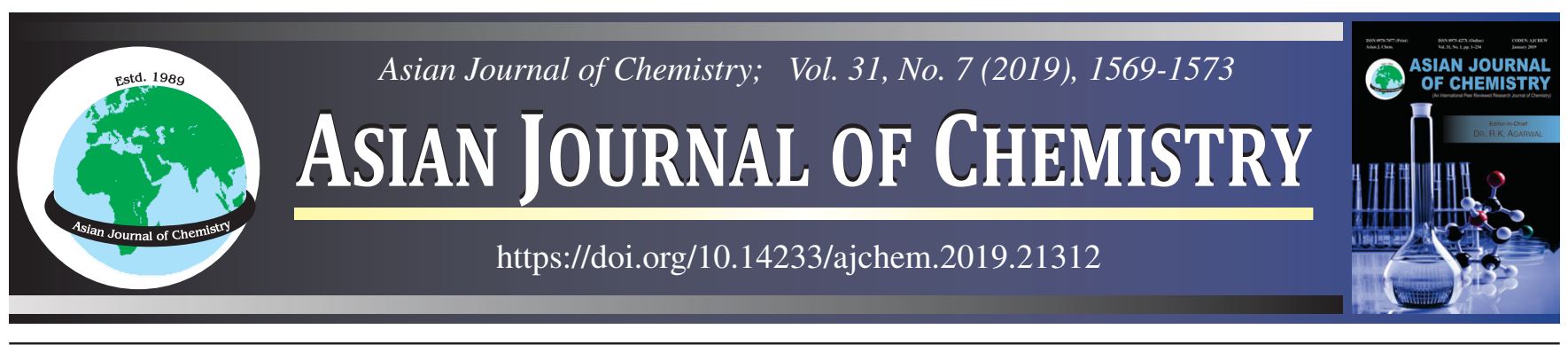

\title{
Antioxidant Activities, Phenolic, Flavonoid and Tannin Contents and Antibacterial Activity of Anvillea radiata (Coss. \& Dur.) Flowers from Southeast Algeria
}

\section{S. Mahdjar*, ${ }^{*}$, H. Dendougui and M. Hadjadj}

Laboratory of Valorisation and Promotion of Saharan Resources, Faculty of Mathematics and Science of Matter, University of Ouargla, Ouargla, Algeria

*Corresponding author: Tel: +213 66 2927924; E-mail: salhama@ymail.com

Received: 3 March 2019;

Accepted: 27 March 2019;

Published online: 21 May 2019;

AJC-19416

Anvillea garcinii subsp. radiata (Coss. \& Dur.) are an endemic species of Sahara region especially in Morocco and Algeria. This plant is widely used in traditional medicine. The extraction of phenolic compounds from A. radiata flowers is carried out using solvents of different polarity (chloroform, ethyl acetate, butanol). The yields of extraction from the flowers were 19.34, 0.278, 0.149, 1.750 and $3.308 \%$ for the crude, chloroform, ethyl acetate, butanol and aqueous extracts, respectively. The amount of total phenolics, flavonoids, tannins and in vitro antioxidant and antibacterial properties of extracts of $A$. radiata flowers. The antioxidant activities were evaluated by measuring the ability of the extracts to scavenge the DPPH, ferric reducing power FRAP and phosphomolybdenum assay. The maximum extractable total phenolics and flavonoids were recorded in ethyl acetate fraction, while the tannins were present in chloroform fraction. Among the five extracts of $A$. radiata flowers, the maximum DPPH free radical scavenging activity was shown in ethyl acetate and butanol fractions $\left(\mathrm{IC}_{50}=0.20 \pm 0.001\right.$ and $0.31 \pm 0.004 \mathrm{mg} / \mathrm{mL}$, respectively). The highest activity of FRAP assay and phosphomolybdenum reduction was observed in butanol fraction $(358.58 \pm 12.55$ and $95.09 \pm 0.67 \mathrm{mM}$, respectively). The results were compared with natural and synthetic antioxidants. In antibacterial properties, the chloroform extract has the highest activity. These results implied that these plant extracts may possess health promoting effects and might be potential sources of potent natural antioxidant and antimicrobial.

Keywords: Anvillea radiata, Antimicrobial activity, Phenolic, flavonoids, Tannins.

ᄂ -

\section{INTRODUCTION}

Medicinal plants are widely used in human therapy, agricultural, scientific research and in several other areas [1]. They are rich source of natural bioactive substances and compounds called secondary metabolites that are the subject of much research in vivo and in vitro [2]. Therapeutic benefits of the medicinal plants are often attributed to their antioxidant properties in relation to their large content on antioxidant compounds such as vitamin C, vitamin E, polyphenol and flavonoids [3]. Natural antioxidants derived from plants, especially phenolics are of considerable interest as dietary supplements or food preservatives. In most cases, phenolics mediate their anticarcinogenic effects by inhibiting all stages of chemical carcinogenesis, initiation, promotion and progression as well as formation of carcinogens from dietary precursors [4].

The genus Anvillea is a small genus of plants belongs to the Asteraceae daisy family, it distributed in the region from
North Africa to Iran, including several Middle Eastern countries, such as Egypt, Palestine and Saudi Arabia [5]. It is found to contain two species which occur in North Africa and Middle East [6]. Anvilleina Maire is reduced to a synonym of Anvillea and the two new combinations are made: A. platycarpa (Maire) and A. garcinii (Burm. f.) (Coss. \& Dur.) ssp. radiata (Coss. \& Dur.) [7].

In this context, specie A. garcinii (subsp.) radiata (Coss. $\&$ Dur.) is renowned for its remarkable traditional use. It is a shrub of stony pastures belonging to the family Asteraceae; $A$. radiata is a small woody shrub, densely branched, $20-50 \mathrm{~cm}$ high. It is tomentose, pubescent and very rameous. Its leaves attenuated in petioles, are toothed or sub-pinnative; its inflorescences, heads with spinescent involucres are formed of yellow orange florets, the outside one $25 \mathrm{~mm}$ long. A. radiata is commonly known in Arabic Nogd sahrâwi Nogd Lhor [8] and in Tamazight "Ajjerg; âwjerg" is also called Arabian oxeye [5].

This is an open access journal, and articles are distributed under the terms of the Creative Commons Attribution-NonCommercial-ShareAlike 4.0 (CC BY-NC-SA 4.0) International License which allows readers to freely read, download, copy, distribute, print, search, or link to the full texts of its articles and to use them for any other lawful non-commercial purpose as long as the original source is duly acknowledged. 
Anvillea radiata is endemic between Algeria and Morocco $[2,9]$ and used in traditional medicine for the treatment of various diseases e.g., gastroenteritis [10], spasms and colic, arthritis and rheumatoid vaginal discharge, colds, hepatitis, diabetes and stomach ailments lung disease and indigestion [9-11], antifungal activity $[1,12,13]$, antimicrobial activity [8], etc. In previous phytochemical studies, parthenolid-9-one, $9 \alpha$-hydroxyparthenolide, $8 \alpha, 9 \alpha$-epoxyparthenolide from $A$. radiata are reported [14]. Some other germacranolides e.g., $9 \alpha$-hydroxy$1 \beta, 10 \alpha$-epoxyparthenolide, $9 \beta$-hydroxyparthenolide, $9 \beta$ hydroxy-1 $\beta, 10 \alpha$-epoxyparthenolide, cis-partenolid-9-one $[9,15,16]$ and five flavonols glycosides were detected in A. garcinii [17] and thirteen flavonoids from which, four aglycones and nine flavonol glycosides were also isolated from $A$. radiata [18]. The objective of this study was to compare antioxidant and antimicrobial activities, total phenolic, flavonoid and tannin contents of extracts of $A$. radiata flowers.

\section{EXPERIMENTAL}

Plant material: The flowers of $A$. radiata were collected during the flowering period from Sahara of Merrara near of Touggourt $\left(33^{\circ}\right.$ Northern latitude, longitude of $6^{\circ}$ East at the altitude of $69 \mathrm{~m}$ ) southeast of Algeria. It was obtained in the month of April 2018. The flower was identified and aunthicated was done on the basis of Quezel and Santa [19] by Dr. Halis Youcef, Touggourt's Scientific and Technical Research Centre for Arid Areas. Plant samples were cleaned, air dried in the shade and well-ventilated place, then grounded and stored in dark.

All the chemicals and reagents were of analytical grade. Folin-Ciocalteu reagent, aluminum chloride, phosphate buffer, potassium ferricyanide, trichloroacetic acid (TCA), ferric chloride, 1,1-diphenyl-2-picrylhydrazyl (DPPH), ammonium molybdate, gallic acid, quercetin, catechin, ascorbic acid, BHA and BHT were procured from Sigma-Aldrich.

Preparation of extract and fractions: Flowers (100 g) of $A$. radiata were extracted thrice at room temperature with $\mathrm{MeOH}-\mathrm{H}_{2} \mathrm{O}(70: 30, \mathrm{v} / \mathrm{v})$ for $48 \mathrm{~h}$. After filtration, the filtrate was evaporated till dryness (19.34 g), recovered with distilled water $(60 \mathrm{~mL})$ and partitioned successively using chloroform $(3 \times 35 \mathrm{~mL})$ giving $0.278 \mathrm{~g}$ of chloroform fraction, ethyl acetate (35 mL) giving $0.149 \mathrm{~g}$ of ethyl acetate fraction and $n$-butanol $(4 \times 35 \mathrm{~mL})$ giving $1.750 \mathrm{~g}$ of butanol fraction. The extracts, also the remaining water fraction $3.308 \mathrm{~g}$, were concentrated under reduced pressure and then redissolved with minimum methanol or water. For antimicrobial activity, crude extract and fractions were collected separately and concentrated using a vacuum evaporator to remove the solvent. Residues were dissolved in pure dimethyl sulfoxide and stored at $4{ }^{\circ} \mathrm{C}$ until analysis.

Determination of total phenolic content (TPC): The total phenolic content in the crude extract and the fractions of A. radiata flowers were determined according to method [20]. Briefly; $0.1 \mathrm{~mL}$ of the extract sample was mixed with $0.5 \mathrm{~mL}$ of a (10\%) Folin-Ciocalteu reagent. After $5 \mathrm{~min}, 2.0 \mathrm{~mL}$ of $(20 \%)$ sodium carbonate were added, the mixture was shaken and reacted for $30 \mathrm{~min}$ at room temperature in the dark. The absorbance was measured at $760 \mathrm{~nm}$. The total phenolic content was expressed as gallic acid equivalents (GAE), in milligrams per gram of extract.

Determination of total flavonoid content (TFC): The total flavonoid content in crude extract and the fractions of A. radiata flowers were determined according to the reported method [21]. Briefly, $0.5 \mathrm{~mL}$ of $2 \% \mathrm{AlCl}_{3}$ in ethanol solution was added to $0.5 \mathrm{~mL}$ of extract. After $0.5 \mathrm{~h}$ incubation at room temperature, the absorbance was measured at $430 \mathrm{~nm}$. The total flavonoid content was expressed as quercetin equivalents (QE).

Determination of total tannin content (TTC): The total tannin content in crude extract and the fractions of flower of A. radiata were estimated by colorimetric method [22]. A $3 \mathrm{~mL}$ of $4 \%$ ethanol vanillin solution and $1.5 \mathrm{~mL}$ of conc. $\mathrm{HCl}$ were added to $0.4 \mathrm{~mL}$ of extract. The mixture was allowed to stand for $15 \mathrm{~min}$, and the absorbance was measured at $500 \mathrm{~nm}$. The total tannin content was expressed as catechin equivalents (CE).

DPPH radical scavenging capacity: Scavenging radical activity of various extracts against stable DPPH was assessed according to reported method [23] with slight modification. Diluted plant extract $(0.1 \mathrm{~mL})$ was added to $1.9 \mathrm{~mL}$ of $0.1 \mathrm{mM}$ $\mathrm{DPPH}^{*}$ in ethanol solution. The solutions were placed in dark at room temperature for $0.5 \mathrm{~h}$. The absorbance of the resulting solution was then noted at $517 \mathrm{~nm}$ and ascorbic acid was used as a positive control. The capability to scavenge the DPPH radical was calculated using the following equation:

$$
\text { DPPH scavenging effect }(\%)=\frac{A_{o}-A_{1}}{A_{o}} \times 100
$$

where $\mathrm{A}_{\circ}$ and $\mathrm{A}_{1}$ are the absorbance at $30 \mathrm{~min}$ of control and sample, respectively. The ascorbic acid and BHA was used as positives control.

Ferric reducing power (FRAP): The ferric reducing activity was estimated based on the method of Benmeddour et al. [24]. Different concentrations of the sample $(1 \mathrm{~mL})$ were mixed with $2.5 \mathrm{~mL}$ phosphate buffer solution (pH 6.6) and $2.5 \mathrm{~mL}$ potassium ferricyanide $(1 \%)$. The resulting solutions were incubated at $50{ }^{\circ} \mathrm{C}$ for $20 \mathrm{~min}$. After incubation, the reaction mixture mixed with $2.5 \mathrm{~mL}$ of $10 \%$ TCA and centrifuged at $3000 \mathrm{rpm}$ for $10 \mathrm{~min} .2 .5 \mathrm{~mL}$ of the supernatant was taken and $2.5 \mathrm{~mL}$ distilled water and $0.5 \mathrm{~mL}$ of ferric chloride $(0.1 \%)$ was added to it. The absorbance was measured at $700 \mathrm{~nm}$, using ascorbic acid as a positive control and the results were expressed as $\mathrm{mM}$ equivalent ascorbic acid.

Phosphomolybdenum assay: Total antioxidant activity was estimated by phosphomolybdenum assay method [25]. The different extracts and the fractions of flowers of $A$. radiata having different extract concentrations $(0.1 \mathrm{~mL})$ were mixed with $1 \mathrm{~mL}$ reagent solution $(0.6 \mathrm{M}$ sulfuric acid, $28 \mathrm{mM}$ sodium phosphate and $4 \mathrm{mM}$ ammonium molybdate). The resulting solutions were incubated in a water bath at $95^{\circ} \mathrm{C}$ for $90 \mathrm{~min}$. The mixture was left to cool at room temperature. The absorbance of the mixture was measured at $695 \mathrm{~nm}$, using ascorbic acid as a positive control and the results were expressed as mM equivalent ascorbic acid.

Antimicrobial activity: The antimicrobial activity was evaluated by paper disc diffusion and micro-dilution methods against Staphylococcus aureus (ATCC 25923), Escherichia coli 
(ATCC 25922) and Pseudomonas aeruginosa (ATCC27853). Microorganisms were obtained from the culture collection of the Institute Pasteur.

Determination of zone of inhibition by disc diffusion assay: This test was performed by the solid medium diffusion method [26]. A diameter discs of $6 \mathrm{~mm}$ cut from Whattman filter paper No. 3, sterilized and impregnated with $10 \mu \mathrm{L}$ per disc of different concentrations of extracts and fractions of flowers of $A$. radiata deposited on the surface of a medium previously inoculated. After incubation at $37^{\circ} \mathrm{C}$ for $24 \mathrm{~h}$, the inhibition zones formed around the discs were measured. Each test was repeated thrice.

Statistical analysis: All experiments were performed with each assay in triplicate. Data are presented as mean \pm standard deviation. $\mathrm{IC}_{50}$ was calculated from linear regression.

\section{RESULTS AND DISCUSSION}

The extraction yield for crude extract was $19.95 \%$ for the fractions, the highest yield was found in water fraction (3.308\%) followed by butanol fraction $(1.750 \%)$, chloroform fraction $(0.278 \%)$ and the lowest yield of extraction was in ethyl acetate fraction $(0.149 \%)$. In the present study, total phenolics, tannins and flavonoids obtained from the extracts/ fractions of A. radiata flowers are presented in Table-1.

\section{TABLE-1}

EXTRACTION YIELD, TOTAL PHENOLICS, FLAVONOIDS AND TANNINS CONTENTS OF A. radiata FLOWERS EXTRACTS

\begin{tabular}{lcccc}
\hline \multicolumn{1}{c}{ Extract } & $\begin{array}{c}\text { Yield } \\
(\%)\end{array}$ & $\begin{array}{c}\text { Total } \\
\text { phenolics }(\mathrm{mg} \\
\text { GAE/g) }\end{array}$ & $\begin{array}{c}\text { Total } \\
\text { falvonoid } \\
(\mathrm{mg} \mathrm{QE} / \mathrm{g})\end{array}$ & $\begin{array}{c}\text { Total } \\
\text { tannin } \\
(\mathrm{mg} \\
\mathrm{CE} / \mathrm{g})\end{array}$ \\
\hline $\begin{array}{l}\text { Chloroform } \\
\text { fraction }\end{array}$ & 0.278 & $39.99 \pm 1.89$ & $4.39 \pm 0.03$ & $6.66 \pm 0.04$ \\
$\begin{array}{l}\text { Ethyl acetate } \\
\text { fraction }\end{array}$ & 0.149 & $647.32 \pm 83.20$ & $46.04 \pm 0.47$ & $4.90 \pm 0.20$ \\
$\begin{array}{l}\text { Butanol fraction } \\
\text { Water fraction }\end{array}$ & 1.750 & $270.22 \pm 11.21$ & $17.94 \pm 0.89$ & $1.18 \pm 0.12$ \\
Crude extract & 19.308 & $68.67 \pm 3.32$ & $2.11 \pm 0.09$ & $2.27 \pm 0.16$ \\
\hline
\end{tabular}

Total phenolics varied from $647.32 \pm 83.20$ to $39.99 \pm$ 1.89 (mg GAE/g extract). Maximum extractable total phenolics and flavonoids were recorded in ethyl acetate fraction (647.32 \pm 83.20 and $46.04 \pm 0.47 \mathrm{mg} \mathrm{QE} / \mathrm{g}$, respectively) followed by butanol fraction $(270.22 \pm 11.21$ and $17.94 \pm 0.89 \mathrm{mg} \mathrm{QE} /$ $\mathrm{g}$, respectively) whereas other extract showed moderate amount of phenolics and flavonoid. Chloroform fraction exhibited lower level of phenolics $(39.99 \pm 1.89 \mathrm{mg} \mathrm{GAE} / \mathrm{g})$ and water fraction have minimum amount of flavonoid when compared to other fraction $(2.11 \pm 0.09 \mathrm{mg} \mathrm{QE} / \mathrm{g})$. The highest amount of tannins was present in chloroform fraction $(6.66 \pm 0.04 \mathrm{mg}$ $\mathrm{CE} / \mathrm{g})$ followed by ethyl acetate fraction $(4.90 \pm 0.20 \mathrm{mg} \mathrm{CE} /$ g) and butanol fraction contained the lowest amount total tannin. The results of Amkraz et al. [27] showed that the extract of $A$. radiata has a polyphenol and flavonoids content equal to $24.13 \mathrm{mg} \mathrm{CE} / \mathrm{g}$ dry matter) and 15.39 (mg ER/g dry matter) however, Mohamad et al. [3] estimated the highest amount of total phenols was in methanolic extract of air dried aerial parts A. radiata.
Antioxidant activity: In the present study, three commonly used antioxidant evaluation methods such as DPPH radical scavenging activity, reducing power assay and phosphomolybdenum scavenging capacity were chosen to determine the antioxidant potential of fractions from $A$. radiata flowers.

DPPH radical scavenging activity: The results on DPPH free radical scavenging activity of the different fractions from A. radiata flowers are shown in Table-2. The absorbance decreases as a result of a colour change from purple to yellow as radical is scavenged by antioxidants through donation of hydrogen to from the stable DPPH molecule.

\begin{tabular}{lccc}
\multicolumn{4}{c}{ TABLE-2 } \\
\multicolumn{4}{c}{ ANTIOXIDANT ACTIVITIES OF THE EXTRACT } \\
AND FRACTIONS OF A. radiate FLOWERS \\
\hline \multicolumn{1}{c}{ Extract } & $\begin{array}{c}\text { DPPH IC } \\
(\mathrm{mg} / \mathrm{mL})\end{array}$ & FRAP $(\mathrm{Mm})$ & $\begin{array}{c}\text { Phosphomoly- } \\
\text { bdenum }(\mathrm{mM})\end{array}$ \\
\hline Chloroform fraction & $12.59 \pm 0.16$ & $2.76 \pm 0.04$ & $54.20 \pm 0.53$ \\
Ethyl acetate fraction & $0.20 \pm 0.001$ & $296.93 \pm 8.14$ & $58.22 \pm 3.95$ \\
Butanol fraction & $0.31 \pm 0.004$ & $358.58 \pm 12.55$ & $95.09 \pm 0.67$ \\
Water fraction & $8.19 \pm 0.12$ & $160.60 \pm 13.88$ & $16.07 \pm 1.25$ \\
Crude extract & $0.59 \pm 0.04$ & $85.19 \pm 1.11$ & $18.57 \pm 0.39$ \\
BHA & $0.08 \pm 0.002$ & $1.09 \pm 0.03$ & $0.25 \pm 0.01$ \\
BHT & - & $1.91 \pm 0.03$ & $0.59 \pm 0.08$ \\
\hline
\end{tabular}

$\mathrm{IC}_{50}$ values (the concentration required to inhibit radical formation by $50 \%$ ) for DPPH radical under the experimental condition was determined. Therefore, lower value of $\mathrm{IC}_{50}$ indicates a higher antioxidant activity. The best free radical scavenging activity was exerted by ethyl acetate and butanol fractions showed comparable levels of free radical scavenging activity $(0.31 \pm 0.004 \mathrm{mg} / \mathrm{mL})$. The free radical scavenging activity was found to be least in chloroform fraction $(12.59 \pm 0.16 \mathrm{mg} / \mathrm{mL})$.

This result concurred with Mohamad et al. [3], which showed that ethyl acetate extract of $A$. radiata has the best DPPH free radical scavenging activity value was $87.06 \pm 1.43 \mu \mathrm{g} / \mathrm{mL}$.

Ferric reducing antioxidant power (FRAP) assay: The antioxidant potential of different fractions of $A$. radiata flowers were estimated from their ability to reduce the ferricyanide complex $\left(\mathrm{Fe}^{3+}\right)$ to ferrous form $\left(\mathrm{Fe}^{2+}\right)$, which is recorded by measuring the formation of Perl's Prussian blue at $700 \mathrm{~nm}$. Higher FRAP values indicates higher reducing potency. The FRAP values of fractions of $A$. radiata flowers are depicted in Table-2. Among them butanol fraction registered higher antioxidant activity $(358.58 \pm 12.55 \mathrm{mM})$ followed by ethyl acetate fraction $(296.93 \pm 8.14 \mathrm{Mm})$. All the samples showed reducing power but not at the same level. The order of results of the reduction capacity decrease in the following order: butanol fraction $>$ ethyl acetate fraction $>$ chloroform fraction $>$ crude extract $>$ water fraction. All the extracts showed a good ferric reducing activity, better than BHA or BHT.

An abundant total phenolics in several medicinal plants exhibited higher FRAP values. The reductive ability of samples assessed in this study suggested that all the extracts were able to donate electrons. Hence, they should be able to donate electrons to free radicals in effective biological activities.

Phosphomolybdenum assay: The phosphomolybdenum method is based on the reduction of phosphate-Mo(VI) to phosphate-Mo(V) by the sample and subsequent formation of 
TABLE-3

ANTIBACTERIAL ACTIVITY OF A. radiata EXTRACTS

\begin{tabular}{lcccc}
\hline \multirow{2}{*}{ Extract } & \multirow{2}{*}{ Conc. $(\mathrm{mg} / \mathrm{mL})$} & \multicolumn{3}{c}{ Bacterial agent } \\
\cline { 3 - 5 } & & E. coli ATCC 25922 (-) & S. aureus ATCC 25923 (+) & P. aeruginosa ATCC 27853 (-) \\
\hline Chloroform fraction & 71.6 & $20 \mathrm{~mm}$ & $17 \mathrm{~mm}$ & $9 \mathrm{~mm}$ \\
Ethylacetate fraction & 71.53 & $11 \mathrm{~mm}$ & $10 \mathrm{~mm}$ & - \\
Butanol fraction & 423.4 & $11.5 \mathrm{~mm}$ & $11.5 \mathrm{~mm}$ & $8.5 \mathrm{~mm}$ \\
Water fraction & 238.08 & - & - & - \\
Crude extract & 108.5 & - & $11 \mathrm{~mm}$ & - \\
\hline Included disc diameter $(6 \mathrm{~mm}) ;-=$ No zone of inhibition. &
\end{tabular}

a bluish green coloured phosphate $/ \mathrm{Mo}(\mathrm{V})$ complex at acidic $\mathrm{pH}$. This method is applied to evaluate the total antioxidant capacity of plant extracts [25]. All the fractions exhibited good phosphomolybdenum scavenging capacity, where butanol fraction showed the highest activity $(95.09 \pm 0.67 \mathrm{mM})$ whereas water fraction exhibited lower activity $(16.07 \pm 1.25 \mathrm{mM})$. The phosphomolybdenum values of fractions $A$. radiata flowers are depicted in Table-2.

An antioxidant may be defined as 'a substance that when present at low concentrations compared with that of an oxidizable substrate significantly delays or prevents the oxidation of that substrate [28]. Among the extracts tested, butanol fraction showed promising antioxidant activity that may be due to their rich content of the compounds: aglycones, flavonol glycosides, parthenolid-9-one, $9 \alpha$-hydroxyparthenolide and $8 \alpha, 9 \alpha$ epoxyparthenolide from A. radiata [18].

Antioxidant activity of $A$. radiata as shown by the assays used could be related to their different phenolic content and composition. In other words, antioxidant activity increased proportionally to the phenolic content. Phenols and polyphenolic compounds, such as flavonoids, are widely found in plants, and they showed to possess significant antioxidant activities [4]. The chemical activities of polyphenols in terms of their reducing properties as hydrogen or electron-donating agents predicted their potential for action as free-radical scavengers (antioxidants) [29].

The results of present study established that different extracts of $A$. radiata flowers could chelated the ions and the values are substantial .The hydrogen/electron transfer form antioxidant to DPPH radical and Mo(V) complex occured in the DPPH radical and phosphomolybbdenum assays, respectively. The results of the present study demonstrated that the extracts of $A$. radiata flowers possess significant antioxidant and free radical scavenging activities.

Antimicrobial activity assay: Evaluation of antibacterial activity was perfomed by disk diffusion method in solid medium. The evaluation of this activity was estimated by measuring the action of four fractions on the inhibition zone diameter of three strains of pathogenic bacteria. The results displayed that some fractions showed an appreciable antibacterial activity (Table-3). Among all the studied fractions, the most interesting antibacterial activity was provided by chloroform fraction. In fact, the highest power was observed against Escherichia coli and Staphylococcus aureus with an inhibition zone diameter equal to 20 and $17 \mathrm{~mm}$, respectively. This method has shown that all the extracts (aqueous and solvent extracts) demonstrated activity against species of bacteria tested, suggesting that the medicinal plants could be an important alternative in control of bacterial growth (Table-3).

In the last decades, there has been particular interest in the use of abundant naturally occurring antimicrobials (herbs, spices and plants). This result concurred with Tekwu et al. [30] and Djellouli et al. [31] who reported that chloroform fraction derived from the methanol extract of $A$. radiata was found to be most effective followed by ethyl acetate and butanol fractions. Some extracts showed weakly anticandidal activity [8]. El Hassany et al. [14] reported that $9 \alpha$-hydroxyparthenolide isolated in A. radiata at a concentration of 50 and 100 $\mu \mathrm{g} / \mathrm{disc}$, inhibited the growth of Bacillus cereus (IPL 58605), Streptococcus C (IPT 2-035), Proteus vulgaris (CIP 58605), Enterococcus faecalis (CIP 103214) and Escherichia coli (CIP 54127).

\section{Conclusion}

It is concluded that five different extracts of $A$. radiata were found to be rich in various phytochemicals and possess antioxidant properties. Further studies are needed for the isolation and identification of bioactive compounds responsible for antioxidant and antibacterial activity.

\section{CONFLICT OF INTEREST}

The authors declare that there is no conflict of interests regarding the publication of this article.

\section{REFERENCES}

1. M. Lakhdar, K.H. Meriem, B. Larbi, R. Amina and S. Aicha, World Appl. Sci. J., 26, 165 (2013).

2. A.G. Atanasov, B. Waltenberger, E.-M. Pferschy-Wenzig, T. Linder, C. Wawrosch, P. Uhrin, V. Temml, L. Wang, S. Schwaiger, E.H. Heiss, J.M. Rollinger, D. Schuster, J.M. Breuss, V. Bochkov, M.D. Mihovilovic, B. Kopp, R. Bauer, V.M. Dirsch and H. Stuppner, Biotechnol. Adv., 33, 1582 (2015);

https://doi.org/10.1016/j.biotechadv.2015.08.001.

3. D.-P. Xu, Y. Li, X. Meng, T. Zhou, Y. Zhou, J. Zheng, J.-J. Zhang and H.-B. Li, Int. J. Mol. Sci., 18, 96 (2017); https://doi.org/10.3390/ijms18010096.

4. M.A. Ebrahimzadeh, S. Ehsanifar and B. Eslami, Pharmacogn. Mag., 5, 213 (2009).

5. M. Khan, M.M.S. Abdullah, A.A. Mousa and Z.A. Hamad, Rec. Nat. Prod., 10, 251 (2016).

6. M.A. Boukhris, É. Destandau, A. El Hakmaoui, L. El Rhaffari and C. Elfakir, C. R. Chim., 19, 1124 (2016); https://doi.org/10.1016/j.crci.2016.05.019.

7. A. Anderberg, Nord. J. Bot., 2, 297 (1982); https://doi.org/10.1111/j.1756-1051.1982.tb01193.x.

8. F. Beddou, C. Bekhechi, S. D Chabane and F.A. Bekkara, Int. J. Pharm. Res. Bio-Sci., 3, 175 (2014). 
9. Centre for Mediterranean Cooperation, I.U.C.N.N.R.U., A Guide to Medicinal Plants in North Africa, IUCN Centre for Mediterranean Cooperation (2005).

10. M. Lakhdar, K.H. Meriem, B. Larbi, R. Amina and S. Aicha, World Appl. Sci. J., 26, 165 (2013).

11. M. Bammou, K.E.R. Sellam, B. Lhoussaine, D.T. Eimad, A. Daoudi, J. Ibijbijen and L. Nassiri, Eur. Scient. J., 11, 233 (2015).

12. M. Snoussi, M. Najett, M. Boumediene and M. Abdelallah, Int. J. Pharm. Sci. Res., 9, 1297 (2018); https://doi.org/10.13040/IJPSR.0975-8232.9(3).1297-00.

13. I. Talibi, L. Askarne, H. Boubaker, E.H. Boudyach, F. Msanda, B. Saadi and A. Ait Ben Aoumar, Crop Prot., 35, 41 (2012); https://doi.org/10.1016/j.cropro.2011.12.016.

14. B. El Hassany, F. El Hanbali, M. Akssira, F. Mellouki, A. Haidour and A.F. Barrero, Fitoterapia, 75, 573 (2004); https://doi.org/10.1016/j.fitote.2004.06.003.

15. R. Tyson, C.-J. Chang, J. McLaughlin, Y. Aynehchi and J. Cassady, Cell. Mol. Life Sci., 37, 441 (1981); https://doi.org/10.1007/BF01986119.

16. E. Abdel-Sattar and A.T. McPhail, J. Nat. Prod., 63, 1587 (2000); https://doi.org/10.1021/np000269w.

17. A. Ulubelen, T. Mabry and Y. Aynehchi, J. Nat. Prod., 42, 624 (1979); https://doi.org/10.1021/np50006a007.

18. H. Dendougui, M. Jay, F. Benayache and S. Benayache, Biochem. Syst. Ecol., 34, 718 (2006); https://doi.org/10.1016/j.bse.2006.05.002.

19. P.S. Quezel, Nouvelle flore de l'Algérie et des régions désertiques méridionales (1963).

20. Y.T. Tung, K.C. Cheng, S.T. Ho, Y.L. Chen, T.L. Wu, K.C. Hung and J.H. Wu, J. Food Sci., 76, C701 (2011); https://doi.org/10.1111/j.1750-3841.2011.02178.x.

21. H. Wang, X.D. Gao, G.C. Zhou, L. Cai and W.B. Yao, Food Chem., 106, 888 (2008); https://doi.org/10.1016/j.foodchem.2007.05.068.
22. S. Mariem, F. Hanen, J. Inès, S. Mejdi and K. Riadh, S. Afr. J. Bot., 94, 114 (2014); https://doi.org/10.1016/j.sajb.2014.06.010.

23. P. Wisitsak, J. Nimkamnerd, N. Thitipramote, N. Saewan, P. Chaiwut and P. Pintathong, Comparison of the Bioactive Compounds and Their Activities between Longan and Litchi Seeds Extracts, In Proceeding of 1st Mae Fah Luang University International Conference, Thailand (2012).

24. Z. Benmeddour, E. Mehinagic, D.L. Meurlay and H. Louaileche, J. Funct. Foods, 5, 346 (2013); https://doi.org/10.1016/j.jff.2012.11.005.

25. P. Prieto, M. Pineda and M. Aguilar, Anal. Biochem., 269, 337 (1999); https://doi.org/10.1006/abio.1999.4019.

26. V.K. Gupta, A. Roy, V.K. Nigam and K. Mukherjee, J. Med. Plants Res., 4, 1656 (2010).

27. H. Boubaker, I. Talibi, N. Amkraz, F. Msanda, B. Saadi, E.H. Boudyach and A. Ait-Benaoumar, Afr. J. Biotechnol., 13, 4515 (2014); https://doi.org/10.5897/AJB2014.13831.

28. R. Aeschbach, J. Löliger, B. Scott, A. Murcia, J. Butler, B. Halliwell and O. Aruoma, Food Chem. Toxicol., 32, 31 (1994); https://doi.org/10.1016/0278-6915(84)90033-4.

29. C. Rice-Evans, N. Miller and G. Paganga, Trends Plant Sci., 2, 152 (1997); https://doi.org/10.1016/S1360-1385(97)01018-2.

30. E.M. Tekwu, A.C. Pieme and V.P. Beng, J. Ethnopharmacol., 142, 265 (2012); https://doi.org/10.1016/j.jep.2012.05.005.

31. M. Djellouli, A. Moussaoui, H. Benmehdi, L. Ziane, A. Belabbes, M. Badraoui, N. Slimani and N. Hamidi, Asian J. Nat. Appl. Sci., 2, 59 (2013). 